\title{
Terang Bulan Dance in Karo Society Aesthetic Analysis
}

\author{
Ruth Hertami Dyah Nugrahaningsih', Dilinar Adlin', Inggit Prastiawan ${ }^{3}$ \\ ${ }^{1,2,3}$ Faculty of Languages and Arts, Universitas Negeri Medan, Indonesia \\ hertamiruth@gmail.com
}

\begin{abstract}
Terang Bulan dance is one of the regional creations which is traditionally used by the Karo people in North Sumatra Province. The title of the dance follows the title of the song used as a dance accompaniment song. This dance presents a dramatic effect through the form and variety of movements that are in harmony with the accompanying song. The explanation of the aesthetic value contained in this dance is based on the concept and technique of movement or how to perform the movements which are divided into four parts. The whole movement expresses the aesthetic value content that is manifested in caution, calmness, which emphasizes courtesy in every move.
\end{abstract}

Keywords

analysis, aesthetics, dance

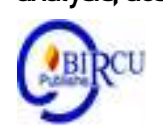

\section{Introduction}

Dance of any ethnic area has a beauty value according to what it expresses. This is also contained in the Terang Bulan dance, a new creation of the Karo community in North Sunatera Province. Even though it is included in the new creation dance category, this dance can be called a traditional new creation dance, because it is always part of various events or activities carried out by the Karo community, even being part of the implementation of traditional activities. In accordance with the choreography form, the Terang Bulan dance is a type of pair dance depicting how a young couple makes love under the full moon.

Traditional dance is the work of human creation and inventiveness which is passed on from one generation to the next. A traditional dance style does not remain in shape. He will always change when taught by the previous generation to the next generation, because the form of dance that is inherited must be interpreted. Traditional dance will continue to be preserved if there is continuous renewal and development by its supporters. Development and renewal can be done by individuals or groups, either in the form of internal perceptions or external perceptions. (Adlin, 2020)

Dance is a statement or reflection of the culture of the supporting community. As a reflection or cultural expression, dance communicates the conditions that exist and are owned by the supporting community. "Dance as a nonverbal language is able to provide the identity adopted by its supporters through the style they have. (Nugrahaningsih, 2020)

According to Febrianto in Martozet (2020) dance is an expression of the soul of human art expressed through beautiful movements and rhythms that give satisfaction to others. The beautiful movements and rhythm are actually the radiance of the human soul and the soul is usually in the form of reason / ideas, will and emotions.Rahmah (2019) states traditional art as one of the material that must be studied, so far has been taught only by oral tradition, focusing on dance

The aesthetic value in this dance can be absorbed not only from the beauty of the form of motion alone, but can be felt when the audience has a sensitivity to the spiritual values contained in this dance, which appear when this dance is physically performed. Crewley in 
Wisnoe Wardhana (1990: 58) says dance is a statement of instinctive style from a vein about a feeling. In other words, dance is the feeling of the dancer channeled through his nerves.

In connection with this, it is important to introduce or convey the aesthetic value contained in the Terang Bulan dance, which is conveyed by a pair of dancers with gentle, calm movements, but contains a strong will or purpose. These values are the result of the dancer's aesthetic experience in communicating with dance according to the sharpness of feeling when abstracting love for their partner, which is then implemented through the movements in the Terang Bulan dance. As a new dance creation, the Terang Bulan dance is composed based on the song Terang Bulan which was composed by Djaga Depari and uses the title song as the name of the dance. There is no binding form or arrangement of motion when expressing this song in the form of motion.

\section{Research Methods}

The location of this study in Faculty of Languages and Arts, Universitas Negeri Medan. This qualitative research is a field research, which is a research that collects data and train information circulating directly to the location or object to be studied, namely faculty of English an art Satete University of Medan. The basic data in this study is the movement of Terang Bulan dance that heal by 2 student.

The qualitative research, testing the validity of data can be achieved by triangulating data and informants. This means that the researcher must clarify the findings of a third person, or the same person at different times. If the information is received, either by another person or the same person, but at different times it still produces the same information, the data is declared "saturated". That's when the validity and reliability of research data has been achieved (Idrus in Akrim, 2020).

\section{Discussion}

An explanation of the analysis the aesthetic of the Terang Bulan dance is based on Humardani's opinion in Dwiyasmono (2013: 187), namely to learn about aesthetics through observing works of art that are recognized as beautiful is to analyze the form of the relationship of the elements. In addition, Soerjodiningrat in Dwiyasmono (2013: 188) states, "Remember kawastanan joged Inggih punika ebahing saranduning body, nice words for wiramaning gendhing. Jumbuhing Pasemon Sarta Pikajenging Jogged". That is, what is called dance is the movement of the whole body, which is arranged with the rhythm of the accompanying song, according to the symbol, meaning and theme of the dance. The aesthetic analysis of this dance describes the form of motion that is structured and has rules in its implementation, related to movement techniques and symbols or symbols and the meaning of their movements. 


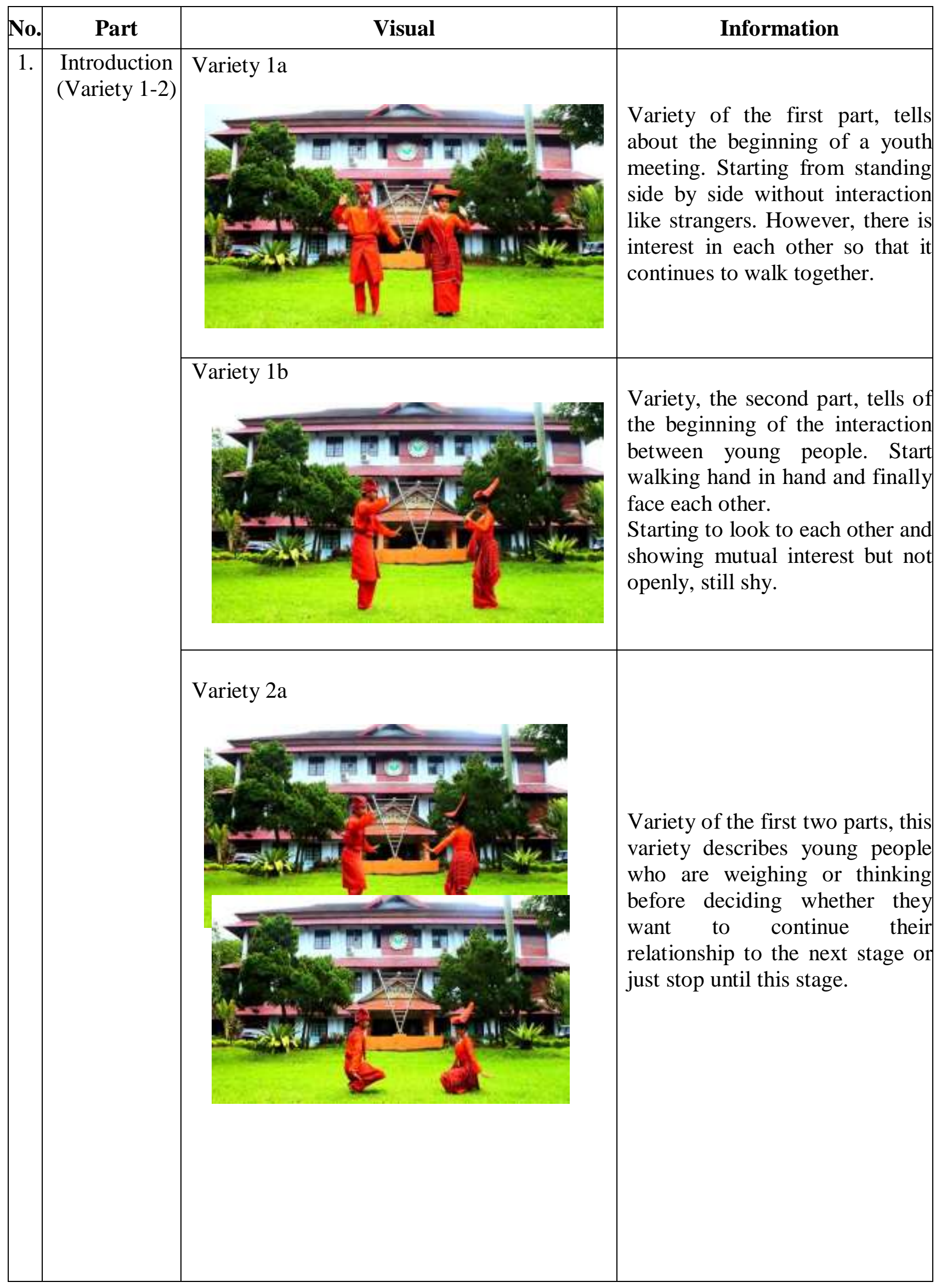




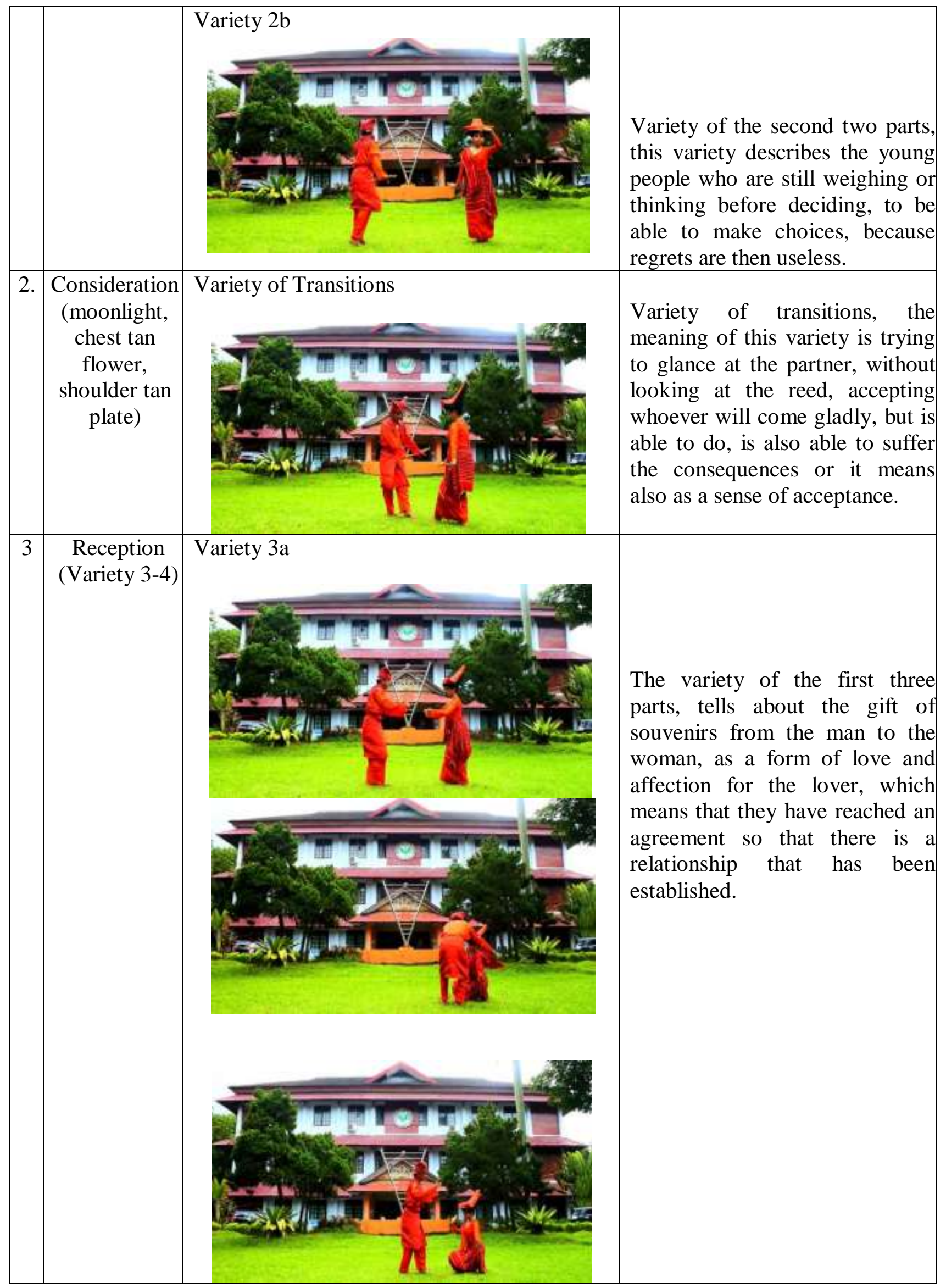




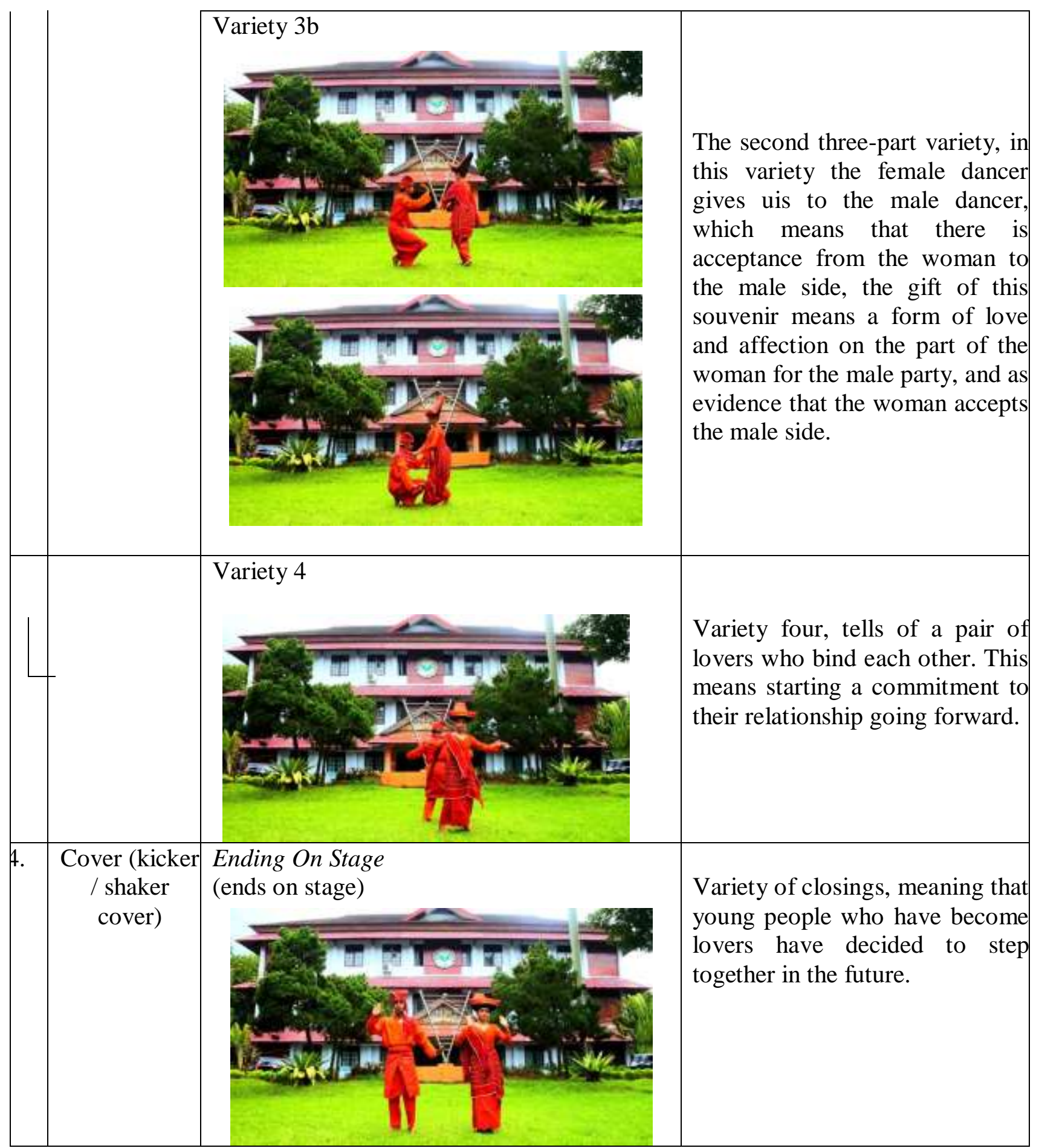




\begin{tabular}{|c|c|c|c|c|c|c|c|c|}
\hline \begin{tabular}{|l} 
No. \\
\end{tabular} & $\begin{array}{l}\text { Movement } \\
\text { Diversity }\end{array}$ & Calculate & $\begin{array}{c}\text { Foot } \\
\text { Movements }\end{array}$ & Hand Movements & Head & Body & nformation & $\begin{array}{c}\text { Movement } \\
\text { Flow }\end{array}$ \\
\hline 1 & & $\begin{array}{l}1 \times 8+ \\
4\end{array}$ & same & Same & Same & Same & $\begin{array}{l}1-4 \\
\text { endek in } \\
\text { front } \\
\text { facing } \\
\text { place, } \\
5-8+4 \\
\text { endek in } \\
\text { place } \\
\text { facing } \\
\text { partner. }\end{array}$ & $\overbrace{\text { xo }}^{\uparrow}$ \\
\hline 2. & $\begin{array}{l}\text { Peek at } \\
\text { the moon } \\
\text { left }\end{array}$ & $1-8$ & $\begin{array}{l}\text { Both legs are } \\
\text { straight and } \\
\text { then } \\
\text { squatting } \\
\text { while being } \\
\text { pushed from } \\
\text { right to left }\end{array}$ & $\begin{array}{l}\text { (LK) The right } \\
\text { hand is located } \\
\text { in front of the } \\
\text { shoulder and the } \\
\text { left hand is } \\
\text { beside the thigh. } \\
\text { (PR) } \\
\text { the right hand is } \\
\text { in front of the } \\
\text { forehead with a } \\
\text { fist distance } \\
\text { from the } \\
\text { forehead, the } \\
\text { thumb and } \\
\text { index finger are } \\
\text { joined together } \\
\text { and the other } \\
\text { finger is flexed } \\
\text { and the left hand } \\
\text { is beside the } \\
\text { thigh. }\end{array}$ & $\begin{array}{l}\text { The } \\
\text { existence } \\
\text { of the head } \\
\text { straight } \\
\text { ahead, } \\
\text { while } \\
\text { glancing at } \\
\text { the partner }\end{array}$ & $\begin{array}{l}\text { Upright } \\
\text { body } \\
\text { motion } \\
\text { while } \\
\text { swingin } \\
\text { g from } \\
\text { right to } \\
\text { left } \\
\text { Follow } \\
\text { the leg } \\
\text { squat } \\
\text { process }\end{array}$ & \begin{tabular}{|l}
$1-6$ \\
squatting \\
process \\
from \\
right to \\
left while \\
kneading \\
, keep the \\
hand \\
position \\
not \\
moving. \\
$7-8$ turn \\
the right \\
hand \\
inwards \\
towards \\
the \\
partner.
\end{tabular} & $\begin{array}{l}\text { Still the } \\
\text { same }\end{array}$ \\
\hline
\end{tabular}




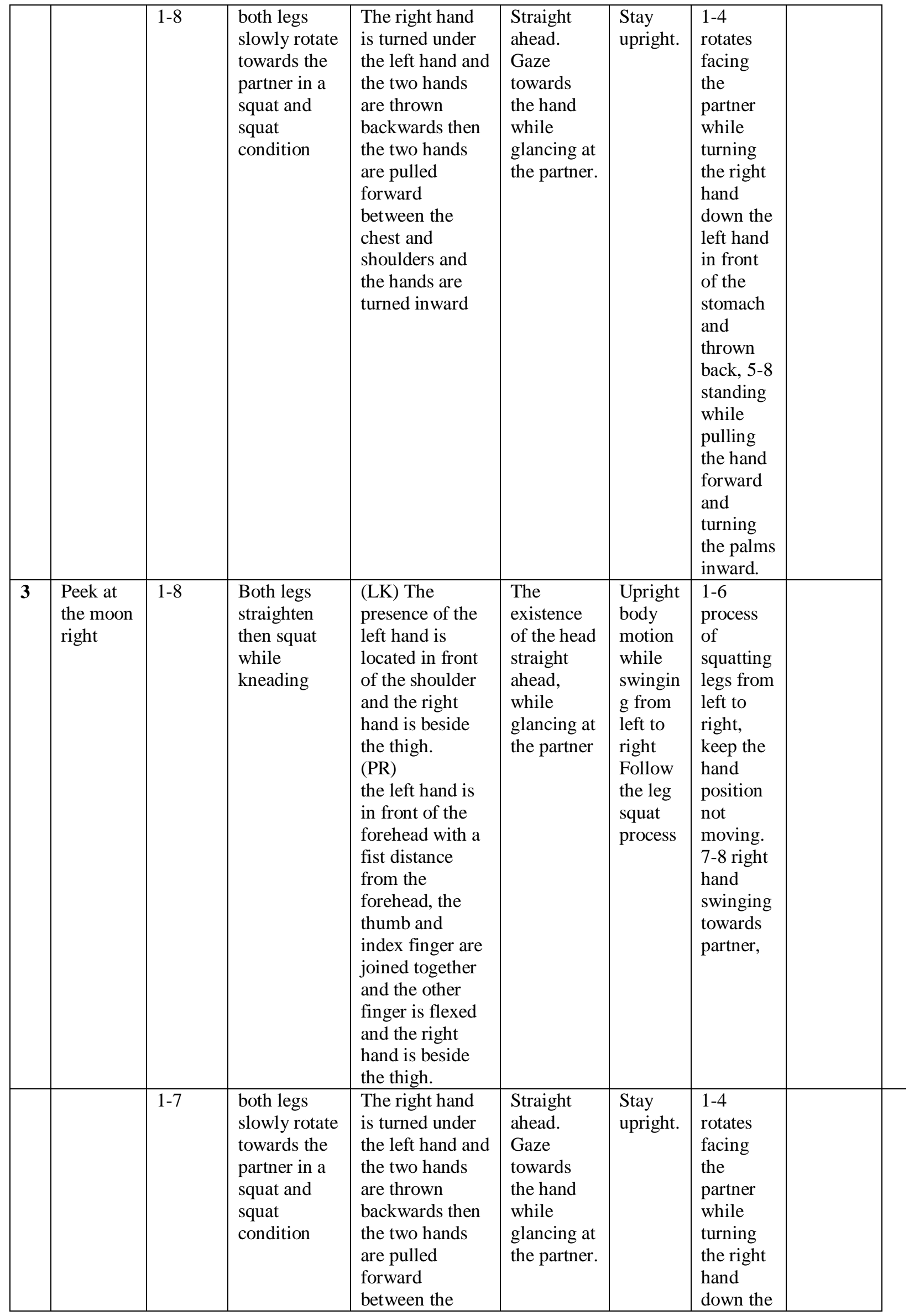




\begin{tabular}{|c|c|c|c|c|c|c|c|}
\hline & & & & $\begin{array}{l}\text { chest and } \\
\text { shoulders and } \\
\text { the hands are } \\
\text { turned inward }\end{array}$ & & & $\begin{array}{l}\text { left hand } \\
\text { in front } \\
\text { of the } \\
\text { stomach } \\
\text { and } \\
\text { throwing } \\
\text { it back, } \\
5-7 \\
\text { standing } \\
\text { while } \\
\text { pulling } \\
\text { the hand } \\
\text { forward } \\
\text { and } \\
\text { turning } \\
\text { the palm } \\
\text { inward. }\end{array}$ \\
\hline 4 & \begin{tabular}{|l|} 
Cucumbe \\
r left
\end{tabular} & 1-4 & $\begin{array}{l}\text { Step left } \\
\text { obliquely at } \\
\text { the start of } \\
\text { the right } \\
\text { foot, and } \\
\text { pose the left } \\
\text { leg crossing } \\
\text { in front of } \\
\text { the right leg } \\
\text { facing } \\
\text { oblique to } \\
\text { the partner }\end{array}$ & $\begin{array}{l}\text { The right hand } \\
\text { is rotated under } \\
\text { the left hand and } \\
\text { the two hands } \\
\text { are thrown } \\
\text { backwards then } \\
\text { pulled in front } \\
\text { of the chest and } \\
\text { turned inward } \\
\text { then the right } \\
\text { hand is dropped } \\
\text { straight in front } \\
\text { of the stomach } \\
\text { and the left hand } \\
\text { is dropped } \\
\text { straight back. }\end{array}$ & $\begin{array}{l}\text { The } \\
\text { existence } \\
\text { of the head } \\
\text { perpendicu } \\
\text { lar to the } \\
\text { front, } \\
\text { glancing at } \\
\text { the couple }\end{array}$ & $\begin{array}{l}\text { The } \\
\text { existen } \\
\text { ce of an } \\
\text { upright } \\
\text { body, } \\
\text { facing } \\
\text { towards } \\
\text { the } \\
\text { footste } \\
\text { ps }\end{array}$ & $\begin{array}{l}\text { 1-4 steps } \\
\text { while the } \\
\text { right } \\
\text { hand is } \\
\text { turned } \\
\text { under the } \\
\text { left hand } \\
\text { and the } \\
\text { two } \\
\text { hands are } \\
\text { thrown } \\
\text { backwar } \\
\text { ds then } \\
\text { pulled in } \\
\text { front of } \\
\text { the chest } \\
\text { and } \\
\text { turned } \\
\text { inward } \\
\text { then the } \\
\text { right } \\
\text { hand is } \\
\text { dropped } \\
\text { straight } \\
\text { in front } \\
\text { of the } \\
\text { stomach } \\
\text { and the } \\
\text { left hand } \\
\text { is } \\
\text { dropped } \\
\text { straight } \\
\text { back, } \\
\text { then } \\
\text { (POSE) }\end{array}$ \\
\hline
\end{tabular}




\begin{tabular}{|c|c|c|c|c|c|c|c|}
\hline & & $5-8$ & $\begin{array}{l}\text { Move back } \\
\text { to the } \\
\text { previous } \\
\text { position } \\
\text { starting with } \\
\text { the left foot }\end{array}$ & $\begin{array}{l}\text { e right hand is } \\
\text { turned under the } \\
\text { left hand and the } \\
\text { two hands are } \\
\text { thrown } \\
\text { backwards then } \\
\text { the two hands } \\
\text { are pulled } \\
\text { forward } \\
\text { between the } \\
\text { chest and } \\
\text { shoulders and } \\
\text { the hands are } \\
\text { turned inward }\end{array}$ & $\begin{array}{l}\text { Head } \\
\text { facing } \\
\text { forward. A } \\
\text { glance at } \\
\text { the couple }\end{array}$ & $\begin{array}{l}\text { The } \\
\text { existen } \\
\text { ce of an } \\
\text { upright } \\
\text { body. }\end{array}$ & $\begin{array}{l}\text { 5-6 feet } \\
\text { backwar } \\
\text { d while } \\
\text { the right } \\
\text { hand is } \\
\text { turned } \\
\text { down the } \\
\text { left hand } \\
\text { in front } \\
\text { of the } \\
\text { stomach } \\
\text { and both } \\
\text { hands are } \\
\text { thrown } \\
\text { backwar } \\
\text { ds, 7-8 } \\
\text { endek in } \\
\text { place } \\
\text { facing } \\
\text { the } \\
\text { partner } \\
\text { and both } \\
\text { hands are } \\
\text { pulled in } \\
\text { front of } \\
\text { the chest } \\
\text { and } \\
\text { turned } \\
\text { inward. }\end{array}$ \\
\hline 4 & $\begin{array}{l}\text { Cucumbe } \\
\text { r right }\end{array}$ & $1-4$ & $\begin{array}{l}\text { Stepping } \\
\text { right } \\
\text { obliquely at } \\
\text { the start of } \\
\text { the left leg, } \\
\text { and crossing } \\
\text { the right leg } \\
\text { in front of } \\
\text { the left leg } \\
\text { facing } \\
\text { oblique to } \\
\text { the partner }\end{array}$ & $\begin{array}{l}\text { The right hand } \\
\text { is turned under } \\
\text { the left hand and } \\
\text { the two hands } \\
\text { are thrown } \\
\text { backwards then } \\
\text { pulled in front } \\
\text { of the chest and } \\
\text { turned inward } \\
\text { then the left } \\
\text { hand is dropped } \\
\text { straight in front } \\
\text { of the stomach } \\
\text { and the right } \\
\text { hand is dropped } \\
\text { straight back. }\end{array}$ & $\begin{array}{l}\text { The } \\
\text { existence } \\
\text { of the head } \\
\text { perpendicu } \\
\text { lar to the } \\
\text { front, } \\
\text { glancing at } \\
\text { the couple }\end{array}$ & $\begin{array}{l}\text { The } \\
\text { existen } \\
\text { ce of an } \\
\text { upright } \\
\text { body, } \\
\text { facing } \\
\text { towards } \\
\text { the } \\
\text { footste } \\
\text { ps }\end{array}$ & $\begin{array}{l}\text { 1-4 steps } \\
\text { while the } \\
\text { right } \\
\text { hand is } \\
\text { rotated } \\
\text { under the } \\
\text { left hand } \\
\text { and both } \\
\text { hands are } \\
\text { thrown } \\
\text { backwar } \\
\text { ds then } \\
\text { pulled in } \\
\text { front of } \\
\text { the chest } \\
\text { and } \\
\text { turned } \\
\text { inward } \\
\text { then the } \\
\text { left hand } \\
\text { is } \\
\text { dropped } \\
\text { straight } \\
\text { in front } \\
\text { of the } \\
\text { stomach } \\
\text { and the } \\
\text { right } \\
\text { hand is } \\
\text { dropped }\end{array}$ \\
\hline
\end{tabular}




\begin{tabular}{|c|c|c|c|c|c|c|c|}
\hline & & & & & & & $\begin{array}{l}\text { straight } \\
\text { back, } \\
\text { then } \\
\text { (POSE) }\end{array}$ \\
\hline & & $5-8$ & $\begin{array}{l}\text { Move back } \\
\text { to the } \\
\text { previous } \\
\text { position } \\
\text { starting with } \\
\text { the right foot }\end{array}$ & $\begin{array}{l}\text { The right hand } \\
\text { is turned under } \\
\text { the left hand and } \\
\text { the two hands } \\
\text { are thrown } \\
\text { backwards then } \\
\text { the two hands } \\
\text { are pulled } \\
\text { forward } \\
\text { between the } \\
\text { chest and } \\
\text { shoulders and } \\
\text { the hands are } \\
\text { turned inward }\end{array}$ & $\begin{array}{l}\text { Head } \\
\text { facing } \\
\text { forward. A } \\
\text { glance at } \\
\text { the couple }\end{array}$ & $\begin{array}{l}\text { The } \\
\text { existen } \\
\text { ce of an } \\
\text { upright } \\
\text { body. }\end{array}$ & $\begin{array}{l}\text { 5-6 feet } \\
\text { backwar } \\
\mathrm{d} \text { while } \\
\text { the right } \\
\text { hand is } \\
\text { rotated } \\
\text { down the } \\
\text { left hand } \\
\text { in front } \\
\text { of the } \\
\text { stomach } \\
\text { and both } \\
\text { hands are } \\
\text { thrown } \\
\text { backwar } \\
\text { ds, 7-8 } \\
\text { endek in } \\
\text { place } \\
\text { facing } \\
\text { the } \\
\text { partner } \\
\text { while the } \\
\text { two } \\
\text { hands are } \\
\text { pulled in } \\
\text { front of } \\
\text { the chest } \\
\text { and } \\
\text { turned } \\
\text { inward. }\end{array}$ \\
\hline 5 & $\begin{array}{l}\text { Forward } \\
\text { turn right }\end{array}$ & $1-8$ & $\begin{array}{l}\text { Starting with } \\
\text { the right } \\
\text { foot, move } \\
\text { forward then } \\
\text { turn right } \\
\text { and return to } \\
\text { face the } \\
\text { partner }\end{array}$ & $\begin{array}{l}\text { The right hand } \\
\text { is rotated under } \\
\text { the left hand and } \\
\text { both hands are } \\
\text { opened for } 1 \\
\text { inch }\end{array}$ & $\begin{array}{l}\text { Head } \\
\text { straight } \\
\text { forward, } \\
\text { gaze } \\
\text { towards } \\
\text { the hands, } \\
\text { occasionall } \\
\text { y glancing } \\
\text { at the } \\
\text { partner }\end{array}$ & $\begin{array}{l}\text { The } \\
\text { existen } \\
\text { ce of an } \\
\text { upright } \\
\text { body. }\end{array}$ & $\begin{array}{l}1-4 \\
\text { forwards } \\
\text { starting } \\
\text { with the } \\
\text { right } \\
\text { foot, 5-8 } \\
\text { turning } \\
\text { to the } \\
\text { right } \\
\text { starting } \\
\text { with the } \\
\text { right foot } \\
\text { and } \\
\text { returning } \\
\text { to face } \\
\text { the } \\
\text { partner. }\end{array}$ \\
\hline
\end{tabular}




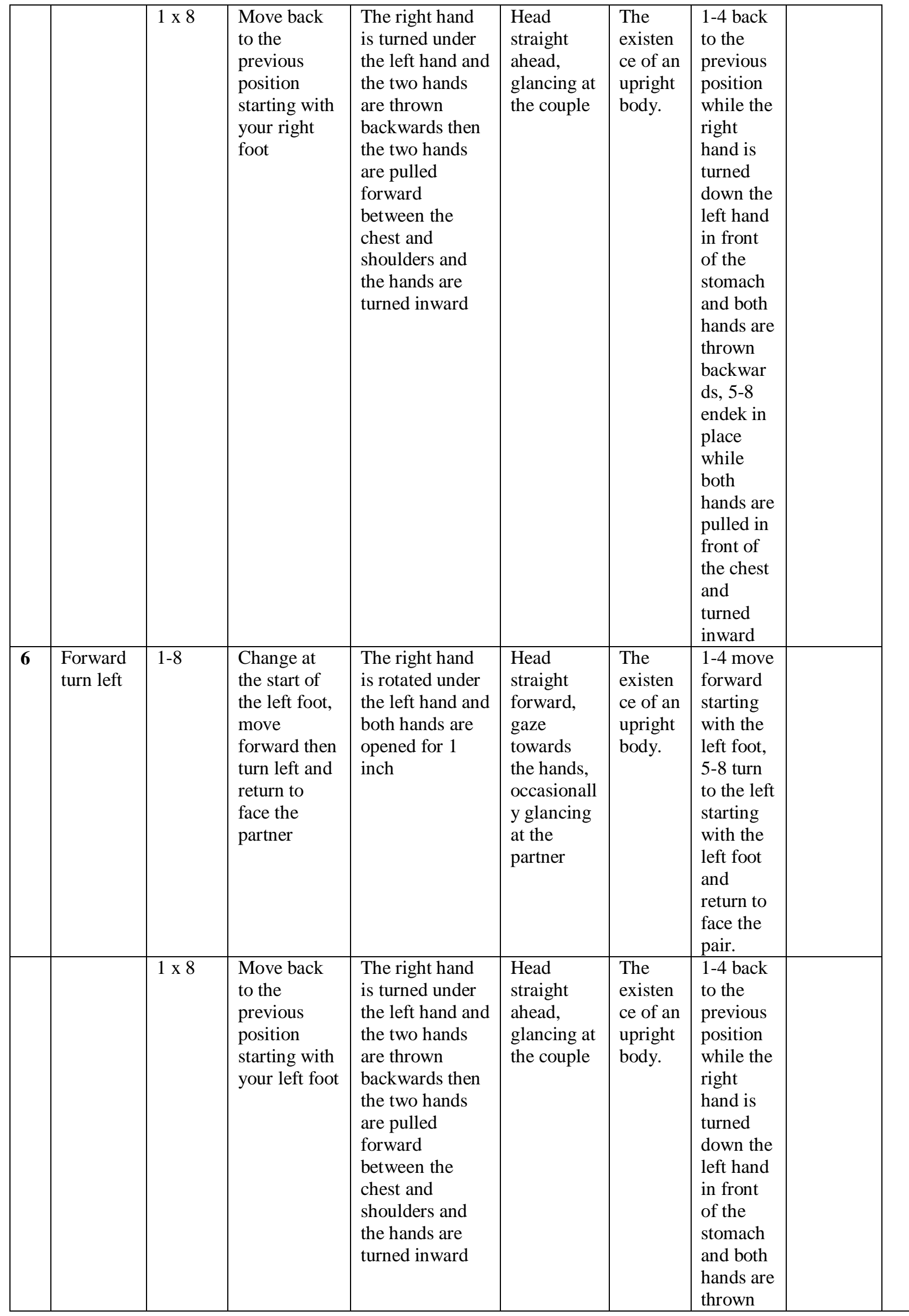




\begin{tabular}{|c|c|c|c|c|c|c|c|}
\hline & & & & & & & $\begin{array}{l}\text { backwar } \\
\text { ds, 5-8 } \\
\text { endek in } \\
\text { place } \\
\text { while } \\
\text { both } \\
\text { hands are } \\
\text { pulled in } \\
\text { front of } \\
\text { the chest } \\
\text { and } \\
\text { turned } \\
\text { inward }\end{array}$ \\
\hline \multirow[t]{2}{*}{7} & $\begin{array}{l}\text { Cucumbe } \\
\text { r left }\end{array}$ & $1-4$ & $\begin{array}{l}\text { Step left } \\
\text { obliquely at } \\
\text { the start of } \\
\text { the right } \\
\text { foot, and } \\
\text { pose the left } \\
\text { leg crossing } \\
\text { in front of } \\
\text { the right leg } \\
\text { facing } \\
\text { oblique to } \\
\text { the partner }\end{array}$ & $\begin{array}{l}\text { The right hand } \\
\text { is rotated under } \\
\text { the left hand and } \\
\text { the two hands } \\
\text { are thrown } \\
\text { backwards then } \\
\text { pulled in front } \\
\text { of the chest and } \\
\text { turned inward } \\
\text { then the right } \\
\text { hand is dropped } \\
\text { straight in front } \\
\text { of the stomach } \\
\text { and the left hand } \\
\text { is dropped } \\
\text { straight back. }\end{array}$ & $\begin{array}{l}\text { The } \\
\text { existence } \\
\text { of the head } \\
\text { perpendicu } \\
\text { lar to the } \\
\text { front, } \\
\text { glancing at } \\
\text { the couple }\end{array}$ & $\begin{array}{l}\text { The } \\
\text { existen } \\
\text { ce of an } \\
\text { upright } \\
\text { body, } \\
\text { facing } \\
\text { towards } \\
\text { the } \\
\text { footste } \\
\text { ps }\end{array}$ & $\begin{array}{l}\text { 1-4 steps } \\
\text { while the } \\
\text { right } \\
\text { hand is } \\
\text { turned } \\
\text { under the } \\
\text { left hand } \\
\text { and the } \\
\text { two } \\
\text { hands are } \\
\text { thrown } \\
\text { backwar } \\
\text { ds then } \\
\text { pulled in } \\
\text { front of } \\
\text { the chest } \\
\text { and } \\
\text { turned } \\
\text { inward } \\
\text { then the } \\
\text { right } \\
\text { hand is } \\
\text { dropped } \\
\text { straight } \\
\text { in front } \\
\text { of the } \\
\text { stomach } \\
\text { and the } \\
\text { left hand } \\
\text { is } \\
\text { dropped } \\
\text { straight } \\
\text { back, } \\
\text { then } \\
\text { (POSE) }\end{array}$ \\
\hline & & 5-8 & $\begin{array}{l}\text { Move back } \\
\text { to the } \\
\text { previous } \\
\text { position } \\
\text { starting with } \\
\text { the left foot }\end{array}$ & $\begin{array}{l}\text { The right hand } \\
\text { is rotated under } \\
\text { the left hand and } \\
\text { both hands are } \\
\text { thrown } \\
\text { backwards then } \\
\text { the two hands } \\
\text { are pulled } \\
\text { forward } \\
\text { between the } \\
\text { chest and }\end{array}$ & $\begin{array}{l}\text { Head } \\
\text { facing } \\
\text { forward. A } \\
\text { glance at } \\
\text { the couple }\end{array}$ & $\begin{array}{l}\text { The } \\
\text { existen } \\
\text { ce of an } \\
\text { upright } \\
\text { body. }\end{array}$ & $\begin{array}{l}\text { 5-6 feet } \\
\text { backwar } \\
\mathrm{d} \text { while } \\
\text { the right } \\
\text { hand is } \\
\text { turned } \\
\text { down the } \\
\text { left hand } \\
\text { in front } \\
\text { of the } \\
\text { stomach }\end{array}$ \\
\hline
\end{tabular}




\begin{tabular}{|c|c|c|c|c|c|c|c|}
\hline & & & & $\begin{array}{l}\text { shoulders and } \\
\text { hands turned } \\
\text { inward }\end{array}$ & & & $\begin{array}{l}\text { and both } \\
\text { hands are } \\
\text { thrown } \\
\text { backwar } \\
\text { ds, 7-8 } \\
\text { endek in } \\
\text { place } \\
\text { facing } \\
\text { the } \\
\text { partner } \\
\text { and both } \\
\text { hands are } \\
\text { pulled in } \\
\text { front of } \\
\text { the chest } \\
\text { and } \\
\text { turned } \\
\text { inward. }\end{array}$ \\
\hline 8. & $\begin{array}{l}\text { Cucumbe } \\
\text { r right }\end{array}$ & $1-4$ & $\begin{array}{l}\text { Stepping } \\
\text { right } \\
\text { obliquely at } \\
\text { the start of } \\
\text { the left leg, } \\
\text { and crossing } \\
\text { the right leg } \\
\text { in front of } \\
\text { the left leg } \\
\text { facing } \\
\text { oblique to } \\
\text { the partner }\end{array}$ & $\begin{array}{l}\text { The right hand } \\
\text { is turned under } \\
\text { the left hand and } \\
\text { the two hands } \\
\text { are thrown } \\
\text { backwards then } \\
\text { pulled in front } \\
\text { of the chest and } \\
\text { turned inward } \\
\text { then the left } \\
\text { hand is dropped } \\
\text { straight in front } \\
\text { of the stomach } \\
\text { and the right } \\
\text { hand is dropped } \\
\text { straight back. }\end{array}$ & $\begin{array}{l}\text { The } \\
\text { existence } \\
\text { of the head } \\
\text { perpendicu } \\
\text { lar to the } \\
\text { front, } \\
\text { glancing at } \\
\text { the couple }\end{array}$ & $\begin{array}{l}\text { The } \\
\text { existen } \\
\text { ce of an } \\
\text { upright } \\
\text { body, } \\
\text { facing } \\
\text { towards } \\
\text { the } \\
\text { footste } \\
\text { ps }\end{array}$ & $\begin{array}{l}\text { 1-4 steps } \\
\text { while the } \\
\text { right } \\
\text { hand is } \\
\text { rotated } \\
\text { under the } \\
\text { left hand } \\
\text { and both } \\
\text { hands are } \\
\text { thrown } \\
\text { backwar } \\
\text { ds then } \\
\text { pulled in } \\
\text { front of } \\
\text { the chest } \\
\text { and } \\
\text { turned } \\
\text { inward } \\
\text { then the } \\
\text { left hand } \\
\text { is } \\
\text { dropped } \\
\text { straight } \\
\text { in front } \\
\text { of the } \\
\text { stomach } \\
\text { and the } \\
\text { right } \\
\text { hand is } \\
\text { dropped } \\
\text { straight } \\
\text { back, } \\
\text { then } \\
\text { (POSE) }\end{array}$ \\
\hline & & $5-8$ & $\begin{array}{l}\text { Move back } \\
\text { to the } \\
\text { previous } \\
\text { position } \\
\text { starting with } \\
\text { the right foot }\end{array}$ & $\begin{array}{l}\text { The right hand } \\
\text { is turned under } \\
\text { the left hand and } \\
\text { the two hands } \\
\text { are thrown } \\
\text { backwards then } \\
\text { the two hands }\end{array}$ & $\begin{array}{l}\text { Head } \\
\text { facing } \\
\text { forward. A } \\
\text { glance at } \\
\text { the couple }\end{array}$ & $\begin{array}{l}\text { The } \\
\text { existen } \\
\text { ce of an } \\
\text { upright } \\
\text { body. }\end{array}$ & $\begin{array}{l}5-6 \text { feet } \\
\text { backwar } \\
\mathrm{d} \text { while } \\
\text { the right } \\
\text { hand is } \\
\text { rotated } \\
\text { down the }\end{array}$ \\
\hline
\end{tabular}




\begin{tabular}{|c|c|c|c|c|c|c|c|}
\hline & & & & $\begin{array}{l}\text { are pulled } \\
\text { forward } \\
\text { between the } \\
\text { chest and } \\
\text { shoulders and } \\
\text { the hands are } \\
\text { turned inward }\end{array}$ & & & $\begin{array}{l}\text { left hand } \\
\text { in front } \\
\text { of the } \\
\text { stomach } \\
\text { and both } \\
\text { hands are } \\
\text { thrown } \\
\text { backwar } \\
\text { ds, 7-8 } \\
\text { endek in } \\
\text { place } \\
\text { facing } \\
\text { the } \\
\text { partner } \\
\text { while the } \\
\text { two } \\
\text { hands are } \\
\text { pulled in } \\
\text { front of } \\
\text { the chest } \\
\text { and } \\
\text { turned } \\
\text { inward. }\end{array}$ \\
\hline 9 & $\begin{array}{l}\text { Endek in } \\
\text { a place } \\
\text { facing } \\
\text { the } \\
\text { partner }\end{array}$ & $1-4$ & $\begin{array}{l}\text { Like the } \\
\text { intro }\end{array}$ & Like the intro & $\begin{array}{l}\text { Like the } \\
\text { intro }\end{array}$ & $\begin{array}{l}\text { Like } \\
\text { the } \\
\text { intro }\end{array}$ & $\begin{array}{l}\text { Like the } \\
\text { intro }\end{array}$ \\
\hline 10 & $\begin{array}{l}\text { Install } \\
\text { the uis } \\
\text { (first } \\
\text { install lk, } \\
\text { then } \\
\text { second } \\
\text { pr) }\end{array}$ & $1 \times 8$ & $\begin{array}{l}\text { (LK) } \\
\text { Endek } \\
\text { position, } \\
\text { move } \\
\text { forward } \\
\text { starting with } \\
\text { the right } \\
\text { foot, } \\
\text { stepping to } \\
\text { the right side } \\
\text { starting from } \\
\text { the right } \\
\text { foot. } \\
\text { (PR) } \\
\text { Leg from } \\
\text { standing } \\
\text { squatting } \\
\text { process } \\
\text { while } \\
\text { kneading the } \\
\text { leg rotates to } \\
\text { the left }\end{array}$ & $\begin{array}{l}\text { (LK) Turn the } \\
\text { right hand down } \\
\text { the left hand and } \\
\text { open both hands } \\
1 \text { inch in front } \\
\text { of the stomach. } \\
\text { (PR) } \\
\text { Right hand in } \\
\text { front of the } \\
\text { shoulder and } \\
\text { left hand } \\
\text { straight out to } \\
\text { the side, arms } \\
\text { slightly open }\end{array}$ & $\begin{array}{l}\text { (LK) } \\
\text { Upright } \\
\text { forward, } \\
\text { the view } \\
\text { follows the } \\
\text { flow of the } \\
\text { movement } \\
\text { s of the } \\
\text { hands and } \\
\text { feet. } \\
\text { (PR) } \\
\text { The } \\
\text { position of } \\
\text { the body } \\
\text { from } \\
\text { straight } \\
\text { forward, } \\
\text { facing the } \\
\text { process to } \\
\text { the left }\end{array}$ & $\begin{array}{l}\text { (LK) } \\
\text { Upright } \\
\text {, facing } \\
\text { directio } \\
\mathrm{n} \\
\text { followi } \\
\mathrm{ng} \\
\text { footste } \\
\text { ps. } \\
\text { (PR) } \\
\text { Upright } \\
\text {, facing } \\
\text { directio } \\
\mathrm{n} \\
\text { followi } \\
\text { ng } \\
\text { body } \\
\text { rotation }\end{array}$ & $\begin{array}{l}\text { (LK) 1-4 } \\
\text { forward } \\
\text { starting } \\
\text { from the } \\
\text { right foot } \\
\text { while the } \\
\text { right } \\
\text { hand is } \\
\text { rotated } \\
\text { under the } \\
\text { left hand } \\
\text { and both } \\
\text { hands are } \\
\text { opened } 1 \\
\text { inch in } \\
\text { front of } \\
\text { the } \\
\text { stomach, } \\
5-8 \text { steps } \\
\text { to the } \\
\text { right side } \\
\text { starting } \\
\text { with the } \\
\text { right foot } \\
\text { and the } \\
\text { same } \\
\text { hand as } \\
\text { moving } \\
\text { forward } \\
\text { (PR) } \\
1-4 \text { Legs }\end{array}$ \\
\hline
\end{tabular}




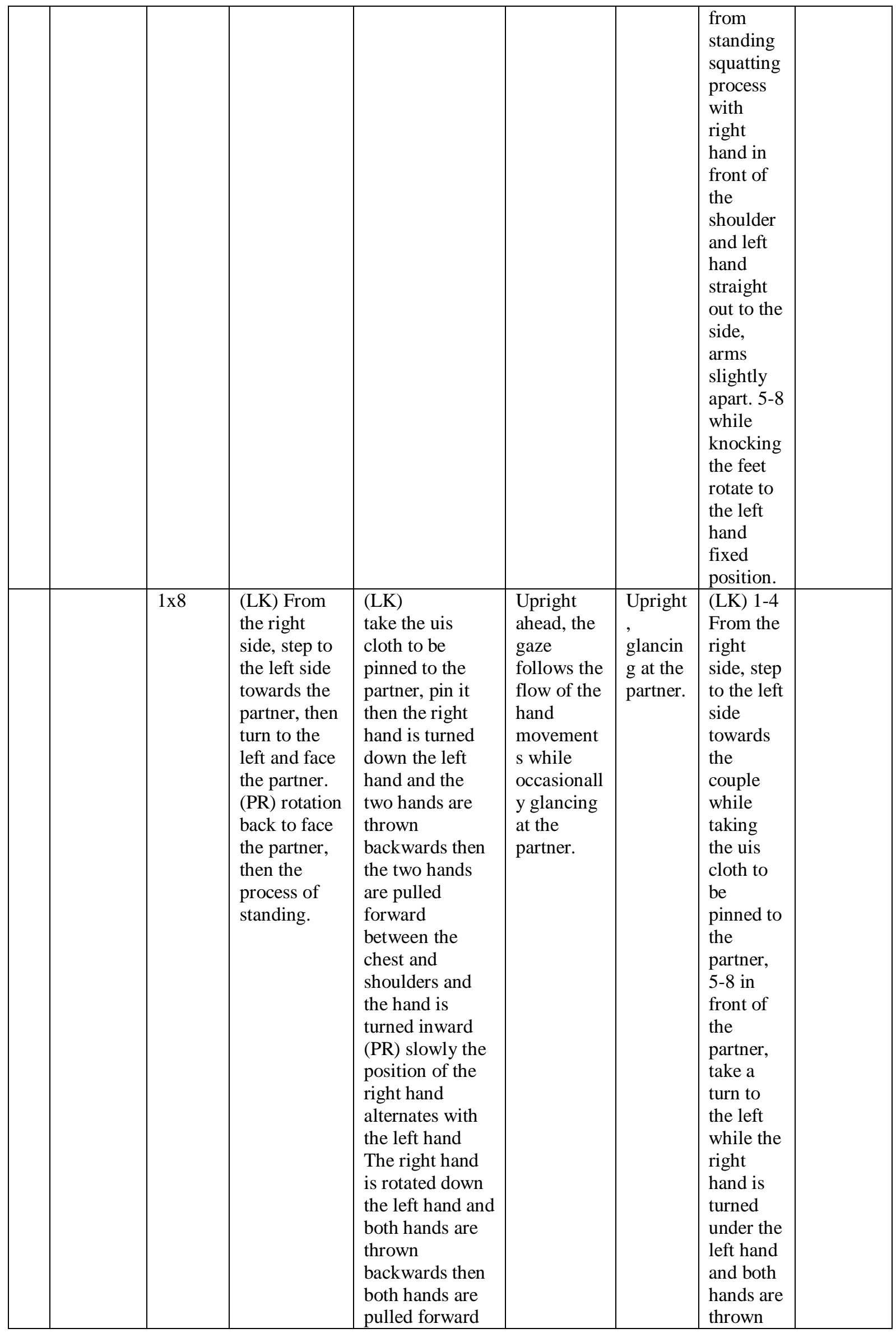




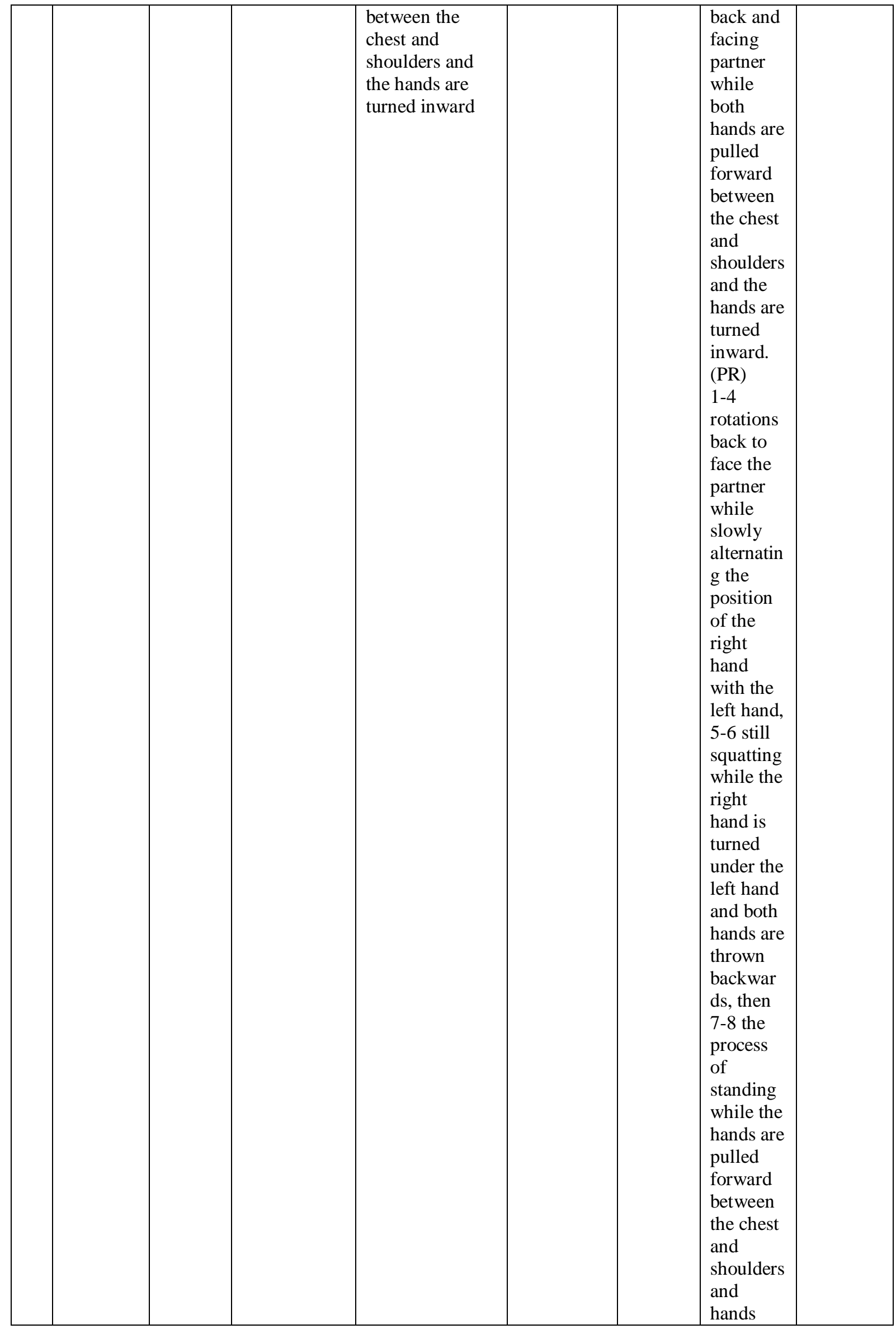




\begin{tabular}{|c|c|c|c|c|c|c|c|}
\hline & & & & & & & $\begin{array}{l}\text { turned } \\
\text { inward. }\end{array}$ \\
\hline 11 & $\begin{array}{l}\text { I } \\
\text { installed } \\
\text { the uis }\end{array}$ & $2 \times 8$ & $\begin{array}{l}\text { Take turns } \\
\text { with your } \\
\text { partner }\end{array}$ & $\begin{array}{l}\text { Take turns with } \\
\text { your partner }\end{array}$ & $\begin{array}{l}\text { Take turns } \\
\text { with your } \\
\text { partner }\end{array}$ & $\begin{array}{l}\text { Take } \\
\text { turns } \\
\text { with } \\
\text { your } \\
\text { partner }\end{array}$ & $\begin{array}{l}\text { Take } \\
\text { turns } \\
\text { with your } \\
\text { partner }\end{array}$ \\
\hline 12 & $\begin{array}{l}\text { Cucumbe } \\
\text { r left }\end{array}$ & $1-4$ & $\begin{array}{l}\text { Step left } \\
\text { obliquely at } \\
\text { the start of } \\
\text { the right } \\
\text { foot, and } \\
\text { pose the left } \\
\text { leg crossing } \\
\text { in front of } \\
\text { the right leg } \\
\text { facing } \\
\text { oblique to } \\
\text { the partner }\end{array}$ & $\begin{array}{l}\text { The right hand } \\
\text { is rotated under } \\
\text { the left hand and } \\
\text { the two hands } \\
\text { are thrown } \\
\text { backwards then } \\
\text { pulled in front } \\
\text { of the chest and } \\
\text { turned inward } \\
\text { then the right } \\
\text { hand is dropped } \\
\text { straight in front } \\
\text { of the stomach } \\
\text { and the left hand } \\
\text { is dropped } \\
\text { straight back. }\end{array}$ & $\begin{array}{l}\text { The } \\
\text { existence } \\
\text { of the head } \\
\text { perpendicu } \\
\text { lar to the } \\
\text { front, } \\
\text { glancing at } \\
\text { the couple }\end{array}$ & $\begin{array}{l}\text { The } \\
\text { existen } \\
\text { ce of an } \\
\text { upright } \\
\text { body, } \\
\text { facing } \\
\text { towards } \\
\text { the } \\
\text { footste } \\
\text { ps }\end{array}$ & $\begin{array}{l}\text { 1-4 steps } \\
\text { while the } \\
\text { right } \\
\text { hand is } \\
\text { turned } \\
\text { under the } \\
\text { left hand } \\
\text { and the } \\
\text { two } \\
\text { hands are } \\
\text { thrown } \\
\text { backwar } \\
\text { ds then } \\
\text { pulled in } \\
\text { front of } \\
\text { the chest } \\
\text { and } \\
\text { turned } \\
\text { inward } \\
\text { then the } \\
\text { right } \\
\text { hand is } \\
\text { dropped } \\
\text { straight } \\
\text { in front } \\
\text { of the } \\
\text { stomach } \\
\text { and the } \\
\text { left hand } \\
\text { is } \\
\text { dropped } \\
\text { straight } \\
\text { back, } \\
\text { then } \\
\text { (POSE) }\end{array}$ \\
\hline & & $5-8$ & $\begin{array}{l}\text { Move back } \\
\text { to the } \\
\text { previous } \\
\text { position } \\
\text { starting with } \\
\text { the left foot }\end{array}$ & $\begin{array}{l}\text { The right hand } \\
\text { is turned under } \\
\text { the left hand and } \\
\text { the two hands } \\
\text { are thrown } \\
\text { backwards then } \\
\text { the two hands } \\
\text { are pulled } \\
\text { forward } \\
\text { between the }\end{array}$ & $\begin{array}{l}\text { Head } \\
\text { facing } \\
\text { forward. A } \\
\text { glance at } \\
\text { the couple }\end{array}$ & $\begin{array}{l}\text { The } \\
\text { existen } \\
\text { ce of an } \\
\text { upright } \\
\text { body. }\end{array}$ & $\begin{array}{l}5-6 \text { feet } \\
\text { backwar } \\
\text { d while } \\
\text { the right } \\
\text { hand is } \\
\text { turned } \\
\text { down the } \\
\text { left hand } \\
\text { in front } \\
\text { of the }\end{array}$ \\
\hline
\end{tabular}




\begin{tabular}{|c|c|c|c|c|c|c|c|}
\hline & & & & $\begin{array}{l}\text { chest and } \\
\text { shoulders and } \\
\text { the hands are } \\
\text { turned inward }\end{array}$ & & & $\begin{array}{l}\text { stomach } \\
\text { and both } \\
\text { hands are } \\
\text { thrown } \\
\text { backwar } \\
\text { ds, 7-8 } \\
\text { endek in } \\
\text { place } \\
\text { facing } \\
\text { the } \\
\text { partner } \\
\text { and both } \\
\text { hands are } \\
\text { pulled in } \\
\text { front of } \\
\text { the chest } \\
\text { and } \\
\text { turned } \\
\text { inward. }\end{array}$ \\
\hline 13 & $\begin{array}{l}\text { Cucumbe } \\
\text { r right }\end{array}$ & $1-4$ & $\begin{array}{l}\text { Stepping } \\
\text { right } \\
\text { obliquely at } \\
\text { the start of } \\
\text { the left leg, } \\
\text { and crossing } \\
\text { the right leg } \\
\text { in front of } \\
\text { the left leg } \\
\text { facing } \\
\text { oblique to } \\
\text { the partner }\end{array}$ & $\begin{array}{l}\text { The right hand } \\
\text { is turned under } \\
\text { the left hand and } \\
\text { the two hands } \\
\text { are thrown } \\
\text { backwards then } \\
\text { pulled in front } \\
\text { of the chest and } \\
\text { turned inward } \\
\text { then the left } \\
\text { hand is dropped } \\
\text { straight in front } \\
\text { of the stomach } \\
\text { and the right } \\
\text { hand is dropped } \\
\text { straight back. }\end{array}$ & $\begin{array}{l}\text { The } \\
\text { existence } \\
\text { of the head } \\
\text { perpendicu } \\
\text { lar to the } \\
\text { front, } \\
\text { glancing at } \\
\text { the couple }\end{array}$ & $\begin{array}{l}\text { The } \\
\text { existen } \\
\text { ce of an } \\
\text { upright } \\
\text { body, } \\
\text { facing } \\
\text { towards } \\
\text { the } \\
\text { footste } \\
\text { ps }\end{array}$ & $\begin{array}{l}\text { 1-4 steps } \\
\text { while the } \\
\text { right } \\
\text { hand is } \\
\text { rotated } \\
\text { under the } \\
\text { left hand } \\
\text { and both } \\
\text { hands are } \\
\text { thrown } \\
\text { backwar } \\
\text { ds then } \\
\text { pulled in } \\
\text { front of } \\
\text { the chest } \\
\text { and } \\
\text { turned } \\
\text { inward } \\
\text { then the } \\
\text { left hand } \\
\text { is } \\
\text { dropped } \\
\text { straight } \\
\text { in front } \\
\text { of the } \\
\text { stomach } \\
\text { and the } \\
\text { right } \\
\text { hand is } \\
\text { dropped } \\
\text { straight } \\
\text { back, } \\
\text { then } \\
\text { (POSE) }\end{array}$ \\
\hline
\end{tabular}




\begin{tabular}{|c|c|c|c|c|c|c|c|}
\hline & & $5-8$ & $\begin{array}{l}\text { Move back } \\
\text { to the } \\
\text { previous } \\
\text { position } \\
\text { starting with } \\
\text { the right foot }\end{array}$ & $\begin{array}{l}\text { Turn the right } \\
\text { hand down the } \\
\text { left hand in } \\
\text { front of the } \\
\text { stomach, and } \\
\text { the two hands } \\
\text { are thrown back } \\
\text { and pulled } \\
\text { forward so that } \\
\text { both hands are } \\
\text { in front of the } \\
\text { body between } \\
\text { the chest and } \\
\text { shoulders. }\end{array}$ & $\begin{array}{l}\text { Head } \\
\text { facing } \\
\text { forward. A } \\
\text { glance at } \\
\text { the couple }\end{array}$ & $\begin{array}{l}\text { The } \\
\text { existen } \\
\text { ce of an } \\
\text { upright } \\
\text { body. }\end{array}$ & $\begin{array}{l}\text { 5-6 feet } \\
\text { backwar } \\
\mathrm{d} \text { while } \\
\text { the right } \\
\text { hand is } \\
\text { rotated } \\
\text { down the } \\
\text { left hand } \\
\text { in front } \\
\text { of the } \\
\text { stomach } \\
\text { and both } \\
\text { hands are } \\
\text { thrown } \\
\text { backwar } \\
\text { ds, 7-8 } \\
\text { endek in } \\
\text { place } \\
\text { facing } \\
\text { the } \\
\text { partner } \\
\text { while the } \\
\text { two } \\
\text { hands are } \\
\text { pulled in } \\
\text { front of } \\
\text { the chest } \\
\text { and } \\
\text { turned } \\
\text { inward. }\end{array}$ \\
\hline 14 & $\begin{array}{l}\text { Endek in } \\
\text { a place } \\
\text { facing } \\
\text { the } \\
\text { partner }\end{array}$ & $1-4$ & $\begin{array}{l}\text { Like the } \\
\text { intro }\end{array}$ & Like the intro & $\begin{array}{l}\text { Like the } \\
\text { intro }\end{array}$ & $\begin{array}{l}\text { Like } \\
\text { the } \\
\text { intro }\end{array}$ & $\begin{array}{l}\text { Like the } \\
\text { intro }\end{array}$ \\
\hline 15 & $\begin{array}{l}\text { Position } \\
\text { swap } \\
\text { rotation } \\
\text { with } \\
\text { partner }\end{array}$ & $1 \times 8$ & $\begin{array}{l}\text { Stepping left } \\
\text { obliquely at } \\
\text { the start of } \\
\text { the right foot } \\
\text { then left foot } \\
\text { forward } \\
\text { facing } \\
\text { oblique with } \\
\text { the partner } \\
\text { and cross } \\
\text { steps } \\
\text { backwards } \\
\text { and cross } \\
\text { steps facing } \\
\text { the partner } \\
\text { while } \\
\text { placing the } \\
\text { pair, rotating } \\
\text { back to its } \\
\text { original } \\
\text { position. }\end{array}$ & $\begin{array}{l}\text { The right hand } \\
\text { is rotated under } \\
\text { the left hand and } \\
\text { the two hands } \\
\text { are opened } 1 \\
\text { inch in front of } \\
\text { the stomach. }\end{array}$ & $\begin{array}{l}\text { Head } \\
\text { facing } \\
\text { forward. } \\
\text { Gaze } \\
\text { towards } \\
\text { hand } \\
\text { gestures } \\
\text { while } \\
\text { glancing at } \\
\text { your } \\
\text { partner } \\
\text { occasionall } \\
\text { y }\end{array}$ & $\begin{array}{l}\text { follow } \\
\text { the } \\
\text { directio } \\
\mathrm{n} \text { of } \\
\text { footwor } \\
\mathrm{k} \text {. }\end{array}$ & $\begin{array}{l}1-2 \\
\text { Stepping } \\
\text { left } \\
\text { oblique } \\
\text { at the } \\
\text { start of } \\
\text { the right } \\
\text { foot then } \\
\text { left foot } \\
\text { forward } \\
\text { facing } \\
\text { oblique } \\
\text { with the } \\
\text { partner } \\
\text { while the } \\
\text { right } \\
\text { hand is } \\
\text { turned } \\
\text { down the } \\
\text { left hand } \\
\text { and both } \\
\text { hands are } \\
\text { opened } 1 \\
\text { inch in }\end{array}$ \\
\hline
\end{tabular}




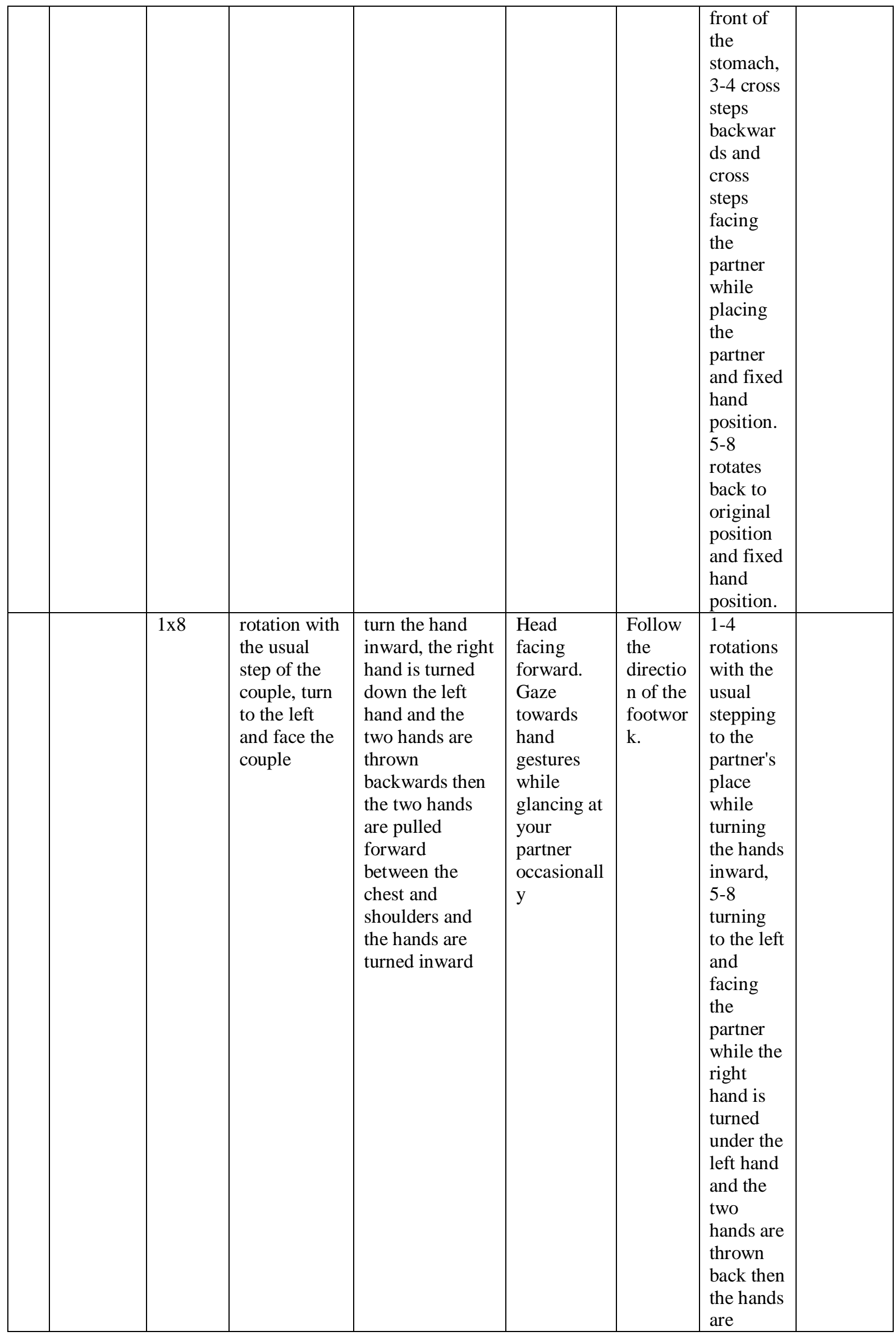




\begin{tabular}{|c|c|c|c|c|c|c|c|}
\hline & & & & & & & $\begin{array}{l}\text { pulled } \\
\text { forward } \\
\text { between } \\
\text { the chest } \\
\text { and } \\
\text { shoulders } \\
\text { and } \\
\text { hands } \\
\text { turned } \\
\text { inward. }\end{array}$ \\
\hline 16 & $\begin{array}{l}\text { The } \\
\text { rotation } \\
\text { of the } \\
\text { original } \\
\text { position } \\
\text { with the } \\
\text { partner }\end{array}$ & $2 \times 8$ & $\begin{array}{l}\text { Same } \\
\text { movement }\end{array}$ & Same movement & $\begin{array}{l}\text { Same } \\
\text { movement }\end{array}$ & $\begin{array}{l}\text { Same } \\
\text { movem } \\
\text { ent }\end{array}$ & $\begin{array}{l}\text { Same } \\
\text { moveme } \\
\text { nt }\end{array}$ \\
\hline 17 & $\begin{array}{l}\text { Cucumbe } \\
\text { r left }\end{array}$ & $1-4$ & $\begin{array}{l}\text { Step left } \\
\text { obliquely at } \\
\text { the start of } \\
\text { the right } \\
\text { foot, and } \\
\text { pose the left } \\
\text { leg crossing } \\
\text { in front of } \\
\text { the right leg } \\
\text { facing } \\
\text { oblique to } \\
\text { the partner }\end{array}$ & $\begin{array}{l}\text { The right hand } \\
\text { is rotated under } \\
\text { the left hand and } \\
\text { the two hands } \\
\text { are thrown } \\
\text { backwards then } \\
\text { pulled in front } \\
\text { of the chest and } \\
\text { turned inward } \\
\text { then the right } \\
\text { hand is dropped } \\
\text { straight in front } \\
\text { of the stomach } \\
\text { and the left hand } \\
\text { is dropped } \\
\text { straight back. }\end{array}$ & $\begin{array}{l}\text { The } \\
\text { existence } \\
\text { of the head } \\
\text { perpendicu } \\
\text { lar to the } \\
\text { front, } \\
\text { glancing at } \\
\text { the couple }\end{array}$ & $\begin{array}{l}\text { The } \\
\text { existen } \\
\text { ce of an } \\
\text { upright } \\
\text { body, } \\
\text { facing } \\
\text { towards } \\
\text { the } \\
\text { footste } \\
\text { ps }\end{array}$ & $\begin{array}{l}\text { 1-4 steps } \\
\text { while the } \\
\text { right } \\
\text { hand is } \\
\text { turned } \\
\text { under the } \\
\text { left hand } \\
\text { and the } \\
\text { two } \\
\text { hands are } \\
\text { thrown } \\
\text { backwar } \\
\text { ds then } \\
\text { pulled in } \\
\text { front of } \\
\text { the chest } \\
\text { and } \\
\text { turned } \\
\text { inward } \\
\text { then the } \\
\text { right } \\
\text { hand is } \\
\text { dropped } \\
\text { straight } \\
\text { in front } \\
\text { of the } \\
\text { stomach } \\
\text { and the } \\
\text { left hand } \\
\text { is } \\
\text { dropped } \\
\text { straight } \\
\text { back, } \\
\text { then } \\
\text { (POSE) }\end{array}$ \\
\hline & & $5-8$ & $\begin{array}{l}\text { Move back } \\
\text { to the } \\
\text { previous } \\
\text { position } \\
\text { starting with } \\
\text { the left foot }\end{array}$ & $\begin{array}{l}\text { The right hand } \\
\text { is turned under } \\
\text { the left hand and } \\
\text { the two hands } \\
\text { are thrown } \\
\text { backwards then } \\
\text { the two hands }\end{array}$ & $\begin{array}{l}\text { Head } \\
\text { facing } \\
\text { forward. A } \\
\text { glance at } \\
\text { the couple }\end{array}$ & $\begin{array}{l}\text { The } \\
\text { existen } \\
\text { ce of an } \\
\text { upright } \\
\text { body. }\end{array}$ & $\begin{array}{l}5-6 \text { feet } \\
\text { backwar } \\
\mathrm{d} \text { while } \\
\text { the right } \\
\text { hand is } \\
\text { turned } \\
\text { down the }\end{array}$ \\
\hline
\end{tabular}




\begin{tabular}{|c|c|c|c|c|c|c|c|}
\hline & & & & $\begin{array}{l}\text { are pulled } \\
\text { forward } \\
\text { between the } \\
\text { chest and } \\
\text { shoulders and } \\
\text { the hands are } \\
\text { turned inward }\end{array}$ & & & $\begin{array}{l}\text { left hand } \\
\text { in front } \\
\text { of the } \\
\text { stomach } \\
\text { and both } \\
\text { hands are } \\
\text { thrown } \\
\text { backwar } \\
\text { ds, 7-8 } \\
\text { endek in } \\
\text { place } \\
\text { facing } \\
\text { the } \\
\text { partner } \\
\text { and both } \\
\text { hands are } \\
\text { pulled in } \\
\text { front of } \\
\text { the chest } \\
\text { and } \\
\text { turned } \\
\text { inward. }\end{array}$ \\
\hline 18 & $\begin{array}{l}\text { Cucumbe } \\
\text { r right }\end{array}$ & $1-4$ & $\begin{array}{l}\text { Stepping } \\
\text { right } \\
\text { obliquely at } \\
\text { the start of } \\
\text { the left leg, } \\
\text { and crossing } \\
\text { the right leg } \\
\text { in front of } \\
\text { the left leg } \\
\text { facing } \\
\text { oblique to } \\
\text { the partner }\end{array}$ & $\begin{array}{l}\text { The right hand } \\
\text { is turned under } \\
\text { the left hand and } \\
\text { the two hands } \\
\text { are thrown } \\
\text { backwards then } \\
\text { pulled in front } \\
\text { of the chest and } \\
\text { turned inward } \\
\text { then the left } \\
\text { hand is dropped } \\
\text { straight in front } \\
\text { of the stomach } \\
\text { and the right } \\
\text { hand is dropped } \\
\text { straight back. }\end{array}$ & $\begin{array}{l}\text { The } \\
\text { existence } \\
\text { of the head } \\
\text { perpendicu } \\
\text { lar to the } \\
\text { front, } \\
\text { glancing at } \\
\text { the couple }\end{array}$ & $\begin{array}{l}\text { The } \\
\text { existen } \\
\text { ce of an } \\
\text { upright } \\
\text { body, } \\
\text { facing } \\
\text { towards } \\
\text { the } \\
\text { footste } \\
\text { ps }\end{array}$ & $\begin{array}{l}\text { 1-4 steps } \\
\text { while the } \\
\text { right } \\
\text { hand is } \\
\text { rotated } \\
\text { under the } \\
\text { left hand } \\
\text { and both } \\
\text { hands are } \\
\text { thrown } \\
\text { backwar } \\
\text { ds then } \\
\text { pulled in } \\
\text { front of } \\
\text { the chest } \\
\text { and } \\
\text { turned } \\
\text { inward } \\
\text { then the } \\
\text { left hand } \\
\text { is } \\
\text { dropped } \\
\text { straight } \\
\text { in front } \\
\text { of the } \\
\text { stomach } \\
\text { and the } \\
\text { right } \\
\text { hand is } \\
\text { dropped } \\
\text { straight } \\
\text { back, } \\
\text { then } \\
\text { (POSE) }\end{array}$ \\
\hline
\end{tabular}




\begin{tabular}{|c|c|c|c|c|c|c|c|}
\hline & & $5-8$ & $\begin{array}{l}\text { Move back } \\
\text { to the } \\
\text { previous } \\
\text { position } \\
\text { starting with } \\
\text { the right foot }\end{array}$ & $\begin{array}{l}\text { Turn the right } \\
\text { hand down the } \\
\text { left hand in } \\
\text { front of the } \\
\text { stomach, and } \\
\text { the two hands } \\
\text { are thrown back } \\
\text { and pulled } \\
\text { forward so that } \\
\text { both hands are } \\
\text { in front of the } \\
\text { body between } \\
\text { the chest and } \\
\text { shoulders. }\end{array}$ & $\begin{array}{l}\text { Head } \\
\text { facing } \\
\text { forward. A } \\
\text { glance at } \\
\text { the couple }\end{array}$ & $\begin{array}{l}\text { The } \\
\text { existen } \\
\text { ce of an } \\
\text { upright } \\
\text { body. }\end{array}$ & $\begin{array}{l}\text { 5-6 feet } \\
\text { backwar } \\
\text { d while } \\
\text { the right } \\
\text { hand is } \\
\text { rotated } \\
\text { down the } \\
\text { left hand } \\
\text { in front } \\
\text { of the } \\
\text { stomach } \\
\text { and both } \\
\text { hands are } \\
\text { thrown } \\
\text { backwar } \\
\text { ds, 7-8 } \\
\text { endek in } \\
\text { place } \\
\text { facing } \\
\text { the } \\
\text { partner } \\
\text { while the } \\
\text { two } \\
\text { hands are } \\
\text { pulled in } \\
\text { front of } \\
\text { the chest } \\
\text { and } \\
\text { turned } \\
\text { inward. }\end{array}$ \\
\hline 19 & Closing & $1-4$ & $\begin{array}{l}\text { Endek } \\
\text { approaches } \\
\text { the couple, } \\
\text { rotates } \\
\text { towards the } \\
\text { audience } \\
\text { (DEPAN) }\end{array}$ & $\begin{array}{l}\text { both hands are } \\
\text { in front of the } \\
\text { body between } \\
\text { the chest and } \\
\text { shoulders. }\end{array}$ & $\begin{array}{l}\text { Head } \\
\text { facing } \\
\text { forward. A } \\
\text { glance at } \\
\text { the couple }\end{array}$ & $\begin{array}{l}\text { The } \\
\text { existen } \\
\text { ce of } \\
\text { the } \\
\text { body } \\
\text { perpen } \\
\text { dicular } \\
\text { to the } \\
\text { footste } \\
\text { ps. }\end{array}$ & $\begin{array}{l}1-2 \\
\text { Endek } \\
\text { advances } \\
\text { towards } \\
\text { the } \\
\text { partner } \\
\text { and both } \\
\text { hands are } \\
\text { in front } \\
\text { of the } \\
\text { body } \\
\text { between } \\
\text { the chest } \\
\text { and } \\
\text { shoulders } \\
\text {, 3-4 } \\
\text { rotates } \\
\text { towards } \\
\text { the } \\
\text { audience } \\
\text { (front) } \\
\text { with the } \\
\text { fixed } \\
\text { hand } \\
\text { position. }\end{array}$ \\
\hline
\end{tabular}


Completing the data and explanation above, the following is a dance note on techniques for performing all the various movements of the Terang Bulan dance (in the table) below.

\section{NOTES OF MONTHLY LIGHT DANCE MOVEMENT}

\section{Conclusion}

Terang Bulan dance is an aesthetic dance presentation. Manifested through the harmonization of the sense of motion between the two dancers according to the concept, form of motion, and the underlying meaning that is in harmony with the accompanying song. This harmonization is also supported and shaped by the dance performance in interpreting dance themes.

\section{References}

Akrim,(2020). Application of Learning Model Strategies to improve Islamic Learning Outcomes. Budapest International Research and Critics Institute-Journal (BIRCIJournal). P. 1157-1166

Adlin, D. (2020). Aesthetic Concept - Choreography of Piso Surit Dance in Karo Community. Budapest International Research and Critics in Linguistics and Education (BirLE) Journal. P. 172-182.

Dwiyasmono. (2013). Aesthetic Analysis of Driasmara Dance. Greget's Journal Volume 12 No. December 2.

Nugrahaningsih, R. (2020). Manduda Dance in Simalungun Community Dancing Style in a Contextual Perspective. Budapest International Research and Critics in Linguistics and Education (BirLE) Journal. P. 164-171

Martozet and Nurawani. (2020). The Transformation of Karo Traditional Dance Movementin Modern Choreography Form GegehGundala-Gundala. Britain International of Linguistics, Arts andEducation(BIoLAE) Journal. P. 765-775

Wisnoe Wardhana. (1990). Dance Education. Middle School Teacher Book First. Department of Education and Culture. 